Portland State University

PDXScholar

Anthropology Faculty Publications and

Presentations

Anthropology

Summer 2018

\title{
Views Across the Pacific: The Galleon Trade and Its Traces in Oregon
}

\author{
Cameron La Follette \\ Oregon Coast Alliance \\ Douglas Deur \\ Portland State University, deur@pdx.edu
}

Follow this and additional works at: https://pdxscholar.library.pdx.edu/anth_fac

Part of the Archaeological Anthropology Commons, and the Biological and Physical Anthropology

Commons

Let us know how access to this document benefits you.

\section{Citation Details}

Cameron La Follette, \& Douglas Deur. (2018). Views Across the Pacific: The Galleon Trade and Its Traces in Oregon. Oregon Historical Quarterly, 119(2), 160-191.

This Article is brought to you for free and open access. It has been accepted for inclusion in Anthropology Faculty Publications and Presentations by an authorized administrator of PDXScholar. Please contact us if we can make this document more accessible: pdxscholar@pdx.edu. 


\title{
Views Across the Pacific
}

\author{
The Galleon Trade and Its Traces in Oregon
}

\section{CAMERON LA FOLLETTE AND DOUGLAS DEUR}

THROUGH THE MANILA GALLEON TRADE, the Spanish developed the first global system of commerce, linking the continents of the world in a shared story of conquest, trade, wealth, cross-cultural contact, and occasional tragedy. During the seventeenth and eighteenth centuries, that international trade network brought a steady procession of Manila galleons, all carrying people and cargo from around the world, very close to the northwestern part of North America now known as the Oregon coast without directly affecting life there - that is, until that one fateful moment when unusual, tragic circumstances brought riveting and instantaneous change: one of the galleons wrecked on that shore. The wreck immediately changed the lives of people living there, and its legacies - through stories, cargo materials, visible ship wreckage, and laws - have affected Oregon history for all the centuries that followed.

We present here some key parts of that history, first by tracing the events that allowed the Spanish empire to develop a truly international trade network. We then survey the oral traditions of the Nehalem-Tillamook and Clatsop peoples, who witnessed the wreck and interacted with the castaways. By all available evidence, this point of contact seems to have been a momentous event in the lives of the Native peoples of the Oregon coast. In spite of traumatic changes to their communities and cultures during the many generations since the wreck, and the likely conflation of oral traditions regarding various shipwrecks, a clear signal, consistent with what we know or would suspect of Oregon's galleon wreck, comes through in most of their shipwreck stories.

Last, we review the traditions, tales, and treasure-hunters' speculations that grew up as early Euro-American traders in the region listened to the Native American oral traditions and found beeswax, porcelain, and other 


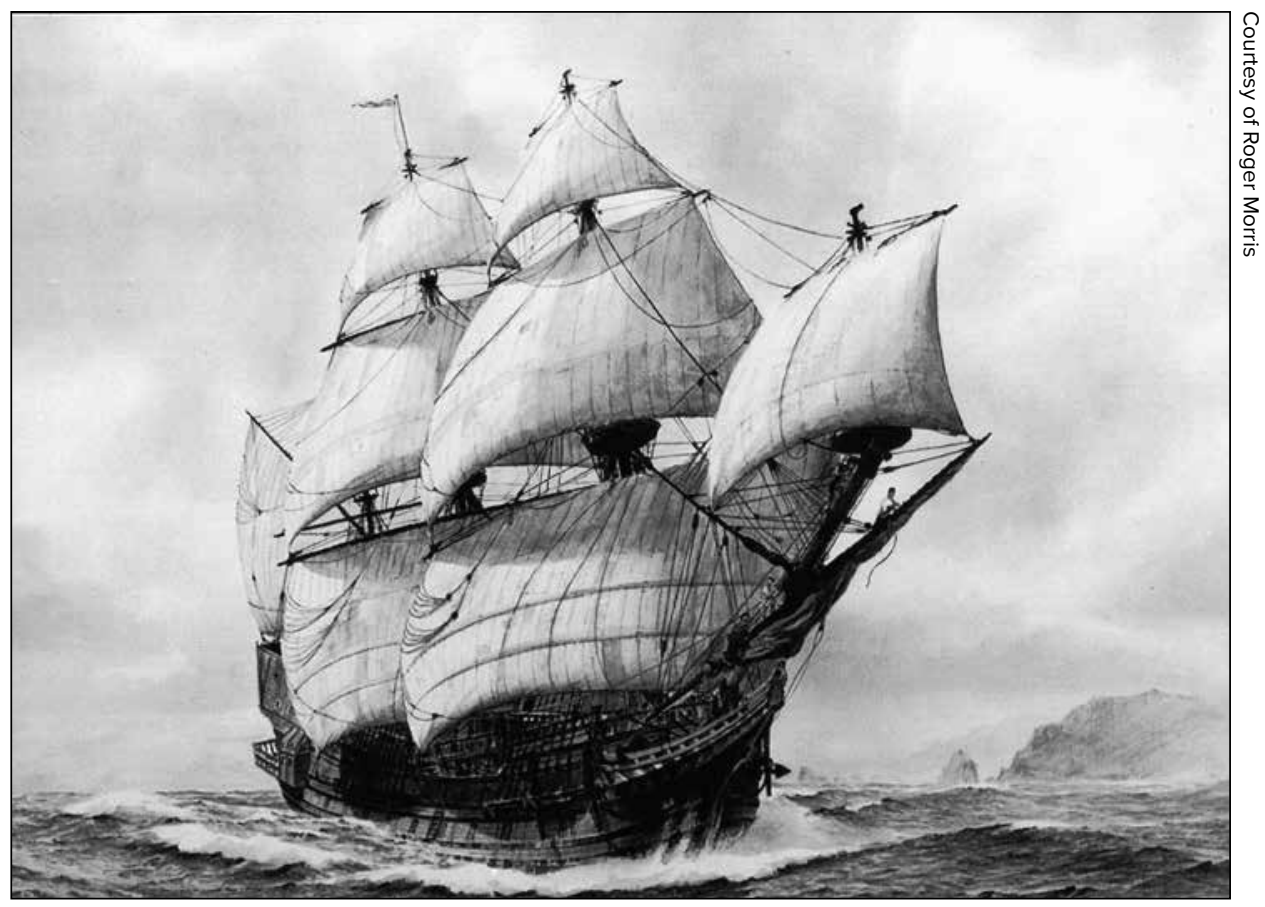

MANILA GALLEONS were large, built for carrying cargo, and described by a contemporary chronicler as "strong castles on the sea." The annual galleon voyage began in Manila, Philippines, where galleons were loaded with the signature Asian trade goods. They sailed across the North Pacific to the coast of North America, and then south to Acapulco. The voyage usually took six to eight months or longer and were beset by storms, poor food, scurvy, and many deaths at sea. This painting by Roger Morris depicts a Manila galleon at sea.

items on the beaches or in the trade goods exchanged among Native peoples. Those first explorers concluded that a large, and most likely Spanish, ship had wrecked in the vicinity. ${ }^{1}$ We survey the use, trade, and sale of the galleon cargo, most especially the beeswax so often mentioned in historical chronicles, first by Nehalem-Tillamook and Clatsop peoples and then by Euro-American settlers. There exist remarkably tenacious traditions of twentieth-century Nehalem-Tillamook and coastal Euro-American residents recalling the locations of the broken ship's gigantic remnants scattered around Nehalem Spit, frequently buried under tides and shifting sands. Euro-American traditions also grew out of the wreck's aftermath and the available Native oral traditions to fashion a fabulous web of tales, weaving 
together hair-raising adventures, battles at sea, romance, and lost treasure. One of the most enduring legacies of the galleon wreck is the lore of buried treasure that fueled decades of fevered treasure hunting from the late nineteenth century into the late 1980 .

The information presented here is both a narrative of the galleon wreck's place in global and local histories as well as context for the articles that follow in this special issue of the Oregon Historical Quarterly. Those articles delve into the archaeological theories behind the wreck's most likely identity, the cargo and people the ship carried, and the twentieth-century laws related to the treasure-hunting and archaeological protection that the wreck inspired.

\section{THE SPANISH EMPIRE AND THE MANILA GALLEON TRADE}

The Spanish were the first Europeans to create permanent settlements in the Americas, and their empire, expanded through a series of bloody conquests, was vast. Beginning in 1519, a mere twenty-seven years after Christopher Columbus's fateful first voyage, the Spanish first conquered the Aztec people of Mexico. Their subsequent conquests of the Maya and other Central American peoples established a firm Spanish foothold in the Americas. But a key turning point in the Spanish conquest was their defeat of the Inca Empire of Peru, beginning in 1532 and continuing for decades thereafter. Spain claimed control over the greater Andes region by 1542, and their conquest and settlement continued into Paraguay and parts of Argentina through the sixteenth century. ${ }^{2}$ This conquest positioned them for the expansion of the Spanish Empire on a global scale, giving them not only access to a vast Pacific coastline but also control over some of the largest silver deposits on the planet. ${ }^{3}$ These events would also place the empire within reach of the Pacific Northwest and of both intentional and accidental encounters with the region's Indigenous peoples. ${ }^{4}$

Once Spain consolidated its control over South America and Central America, it became a formidable global power. Among its premier achievements was inauguration of the world's first global intercontinental trade route: the Manila galleon trade, which shaped economic life on both sides of the Pacific and Atlantic oceans for 250 years. The trade between Spanish colonial ports in the Philippines and Mexico was central to that sprawling network. Access to the world's largest single economy of that time, China, was a primary goal of the d; any nation that could control the flow of Chinese silk, porcelain, spices, precious stones, and luxury goods to Europe and its colonies could achieve unparalleled economic and political power - a sentiment that resonates with modern nations today. In many respects, the successful establishment of the Acapulco-Manila 
trade in the sixteenth century can be seen as a realization of the commercial ambitions and westward reach of Columbus and his sponsors, who had expected to find a sea route to China three-quarters of a century before. Yet, developing a colony on the coast of China was problematic both politically and strategically. Instead, the nearby Philippines gave the Spanish their foothold in Asia and direct access to the spectacular wealth of the continent's mainland. ${ }^{5}$

The Spanish first came to the Philippines in 1521, with the arrival of Ferdinand Magellan - the famed Portuguese navigator, in service of the King of Spain - on his circumnavigation of the world. After a pitched battle in which Magellan was killed, the Spanish fleet withdrew. The Spanish sent several subsequent expeditions to the Philippines, culminating in that of Miguel López de Legázpi in 1565. He established the first Spanish colony in the Philippines, in the Cebu area, and his men also colonized what is now Manila. ${ }^{6}$

This first act of conquest in the Philippines literally charted a course for the entire Manila galleon trade that would follow, due to a critical finding by Andrés de Urdaneta, the Spanish Basque navigator, explorer, and Augustinian friar, who sailed on the Legázpi expedition as a navigator. Urdaneta arrived safely in the Philippines as part of Legázpi's expedition, founded its first churches, and became first prelate of the church in Cebu. Spain's entrepôt secured, Legázpi directed Urdaneta to return to Mexico by way of a route that would allow regular passage of ships eastward across the vast Pacific Ocean. This route was essential if Spain were to establish an Asian trade route between the Philippines and its new colony of Mexico. ${ }^{7}$

Urdaneta reasoned that the trade winds might move in a gyre, and he headed north, off the east coast of Japan. There his ship, the San Pablo, commanded by Felipe de Salcedo, caught the east-blowing winds (confusingly called the "westerlies") that took them across the Pacific to the North American continent. From there, Urdaneta sailed south to Acapulco, arriving in October 1565. He had completed a 12,000-mile voyage across the Pacific Ocean. ${ }^{8}$ For the next two and a half centuries, the galleon trade would follow what became commonly known as "Urdaneta's Route," sailing the northern Pacific currents directly toward what is today the coast of northern California (aiming approximately for Cape Mendocino) in the United States before turning south to Mexico. ${ }^{9}$ This being the sole route for an almost constant procession of annual galleons returning across the Pacific for some two and half centuries, it is not surprising that a galleon, containing the signature cargoes of the Manila-to-Acapulco trade, would one day founder on Oregon's coast. It is the northernmost Spanish galleon wreck known in the Americas. 


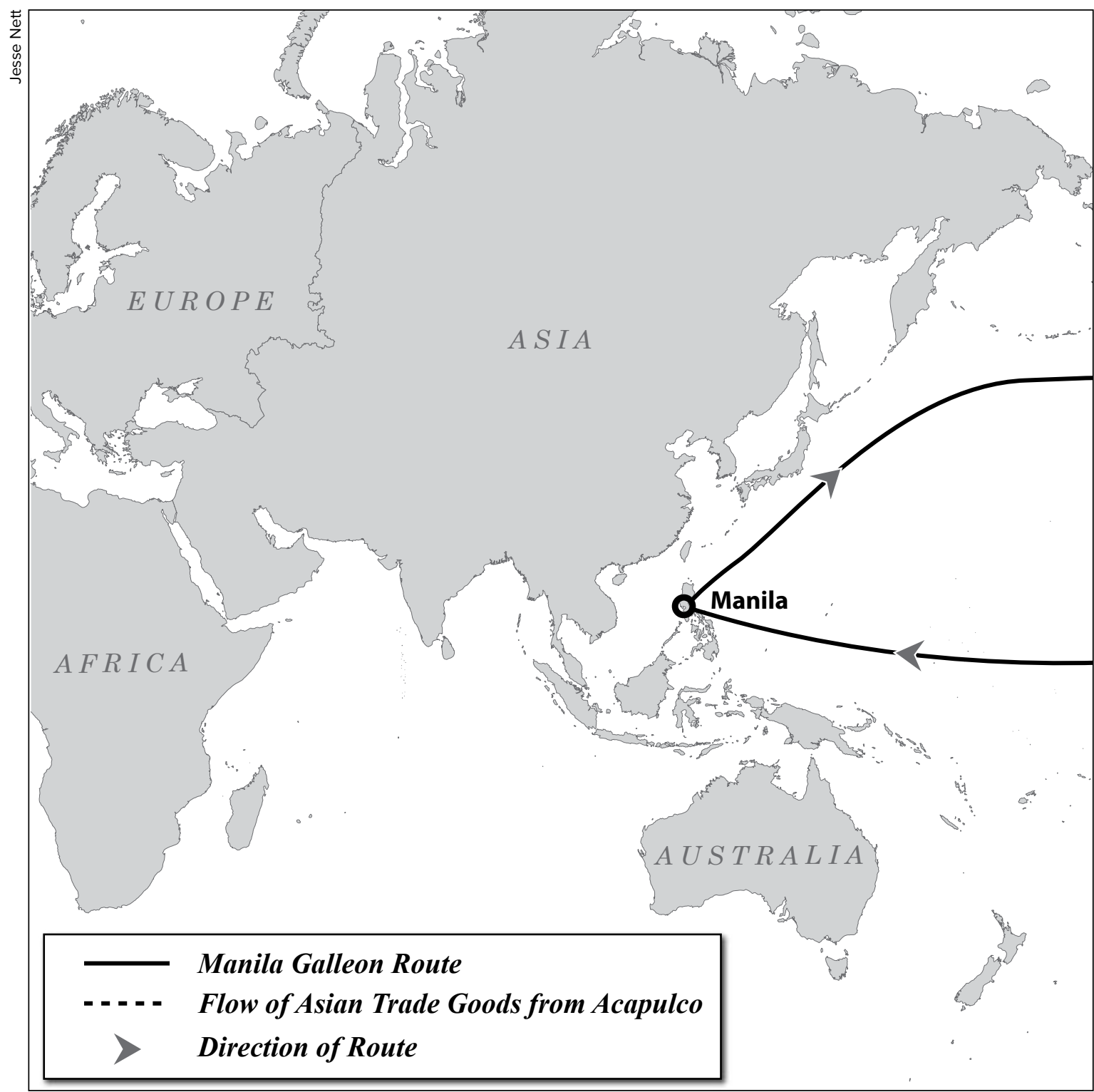

THE MANILA GALLEON ROUTE, pictured above, stretched across the Pacific Ocean from Manila, Philippines, to Acapulco, Mexico, a journey of more than 12,000 miles. To catch the eastblowing trade winds, the galleons had to travel the "Urdaneta route," quite far north of both cities. Once in Mexico, galleon goods were dispersed throughout South America and Europe. 


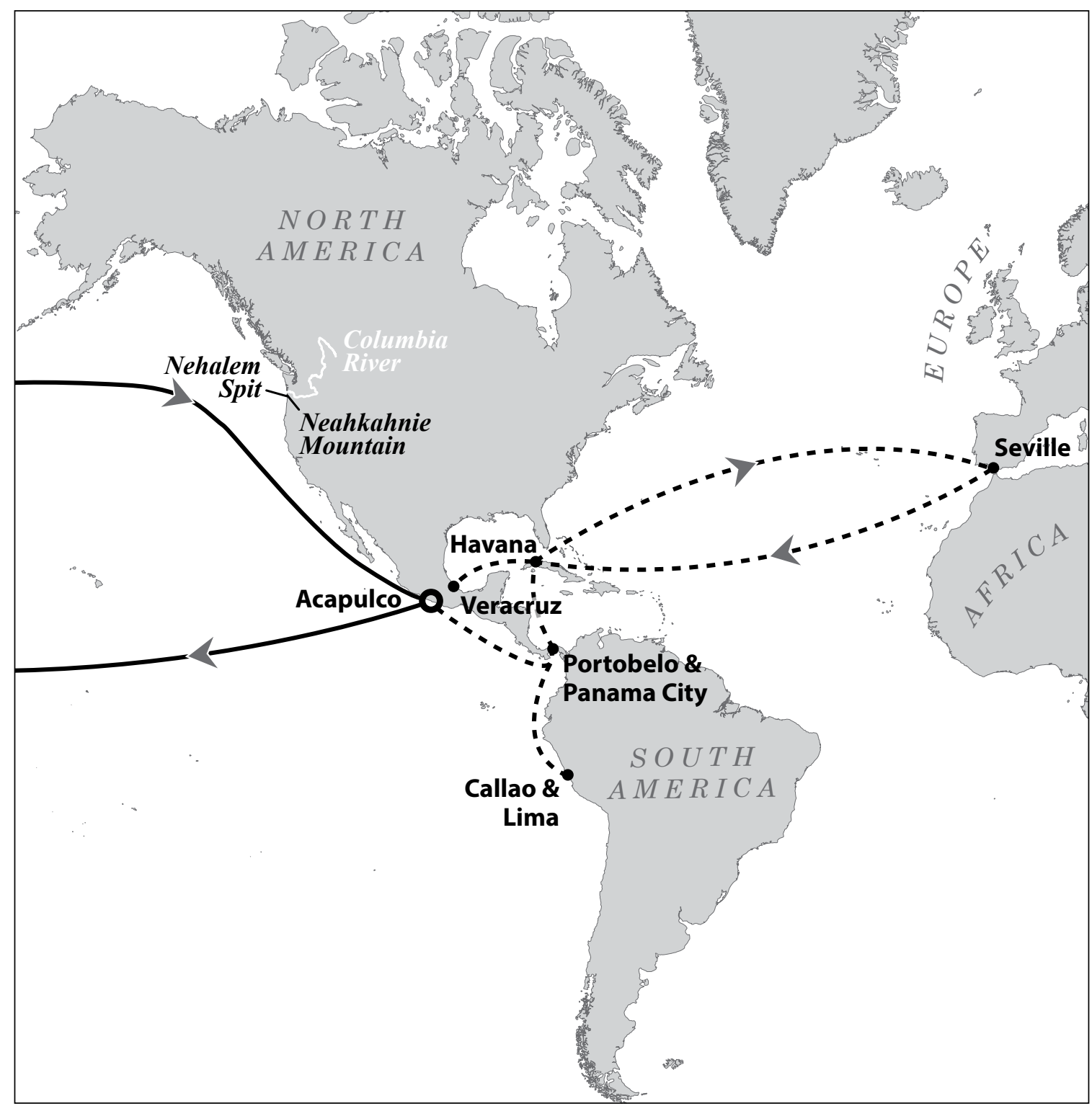


By this world-spanning commercial venture, Spain's merchants were able to tap into local trade networks that had for centuries linked China, Japan, other Southeast Asian kingdoms, and Philippine kingdoms. In the Philippines, the Chinese were drawn especially to trade in natural resources, such as cotton, tortoise shells, pearls, hempen cloth, and "yellow wax."10 The Spanish colonial traders were able to expand that preexisting Asian trade, introducing new goods and new markets alike. Manila had a fine port, and Chinese junks came from the port city of Fujian with coveted Asian trade goods; as the Spanish established themselves, ships also came from Japan and Southeast Asia via long-used local sea routes to participate in the burgeoning Manila trade. ${ }^{11}$ Once the annual galleon arrived in Acapulco, it was unloaded and the cargo dispersed via land routes throughout New Spain and via ship into the Viceroyalty of Peru. Intrepid merchants also took galleon goods overland to Veracruz on the Gulf of Mexico, or to Portobelo across the Isthmus of Panama, and loaded them onto ships returning to Spain. ${ }^{12}$ The goods and global trading activity transformed the lives and economies they touched and contributed greatly to Spain's ascent as one of the wealthiest nations in the world.

For such a staggering journey across the Pacific, only the hardiest and largest vessels would serve. Galleons were the workhorse ships of the Spanish empire, used for trading and war throughout the Atlantic and Pacific. The Manila galleons, however, were specifically not built for speed or maneuverability but for cargo capacity and stability in the open ocean. Merchants and traders wanted ships with as much cargo space as possible, and galleon sizes steadily increased over time. A 1593 law restricted galleons to 300 tons (measured in cargo capacity), but merchants and residents consistently overrode the limits. Before 1614, there were 1,000-ton vessels, and within a few years, some galleons were as large as 2,000 tons in size. ${ }^{13}$ The Manila galleons were the largest ships known in that era and were generally filled with as much cargo as they could hold. These were vast ships by any measure.

It is likely, given the increasing trend in Manila galleon size during this period, that the Santo Cristo de Burgos was between 1,600 and 1,800 tons in size. Although no archival sources have come to light that settle the matter definitively, Italian adventurer Giovanni Gemelli Careri provided an unexpected clue. Careri (1621-1725), who traveled around the world in the late seventeenth century, took the galleon trip from Manila to Acapulco in 1697, only four years after the Santo Cristo disappeared. In the book of his travels, Careri mentions the Santo Cristo and the gravity to the Manila colony of its loss. He described the ship as "Sixty cubits ... in the keel," and reported that a cubit measured a span and a half. ${ }^{14}$ Future archaeo- 
logical investigation may provide verification of the Santo Cristo's size and information on the older, often imprecise, measurement terms used to estimate ship sizes of the era.

Newly established Spanish shipyards in the Philippines began an active galleon-building industry, using conscripted Native Philippine labor for tree-felling and hauling under the watchful eye of Spanish overseers and hiring skilled Chinese carpenters and craftsmen for ship construction and manufacture of tackle and other essential items. Spanish shipwrights estimated it took at least 2,000 or more trees to build a single galleon. All were native Philippine hardwoods, such as teak, which was often used for the ship's outer framework. ${ }^{15}$

The Manila galleon trade has come down through history in stories of fantastic riches and arduous voyages. Both are true. In general, the cargo of the Manila trade consisted of many items, often of exquisite Asian manufacture. As historian Arturo Giraldez notes,

From India came cottons, which in the eighteenth century were an important item of export, second only to Chinese silks. Earthen jars and a wide variety of porcelain arrived from China, alongside rugs from Persia and goods from Japan. Spices like clove, mace, pepper, and cinnamon were brought from the Moluccas, Java and Ceylon.... The galleon also carried gold, jewelry, precious jewels and uncut gems... "Silks in every stage of manufacture and of every variety of weave and pattern formed the most valuable part of their cargoes." 16

Spanish traders had tapped successfully into the preexisting local trade in beeswax, so Manila galleons frequently carried quantities as part of their cargoes. Canon law required candles used at Mass and other rituals in Catholic churches be made primarily of beeswax. Thus, beeswax was harvested in the Philippine colony from Asian bees and shipped to Mexico to be made into candles for personal use and for ceremonies in the churches throughout New Spain, as well as for personal use. ${ }^{17}$ Any galleon foundering on its journey would surely leave beeswax in its wake.

Spanish silver fueled the Manila trade. While other nations had struggled to find goods of interest to Chinese traders, the Spanish almost instantly gained entrance to the full range of Chinese trading networks by providing silver from the Americas. Spanish silver became highly important in the Chinese economy, and Chinese currency was in good part fashioned from silver brought aboard the Manila galleons in payment for trade goods. Ultimately, silver from New Spain and Asian sources, such as Japan, became so central to the Chinese economy that it may have indirectly helped destabilize the Ming dynasty. ${ }^{18}$ 


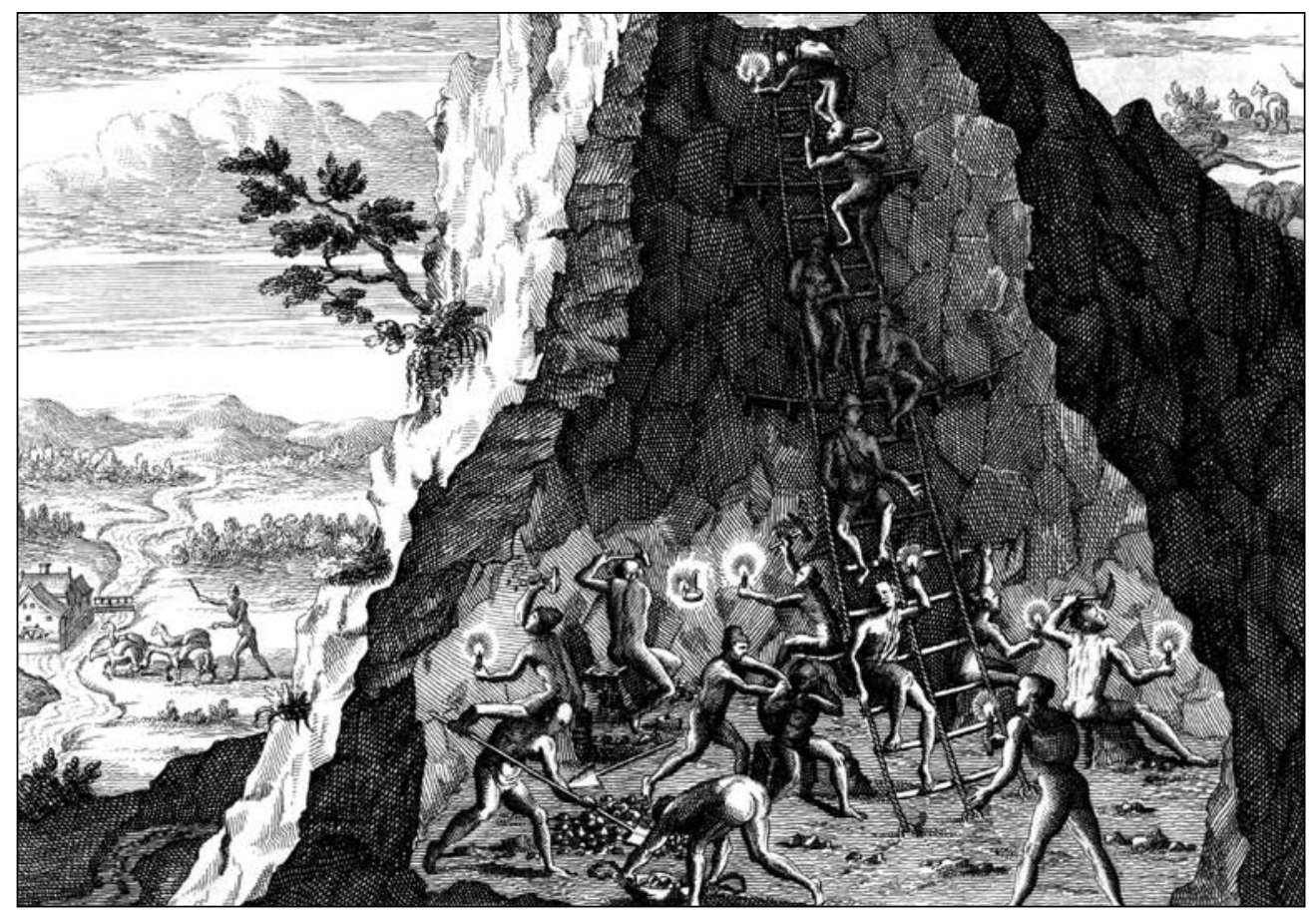

THE CERRO RICO MINE in Potosí, Bolivia, was the richest silver mine in the world. Spain used that silver to purchase the Manila galleon trade goods. Mining took a ghastly toll on the laborers, primarily conscripted Native peoples of the Andes. Conditions were horrific, leading to the mine's nickname, "the mountain that eats men." This 1596 engraving of mining conditions in Potosí by Theodore de Bry was published in Historia Americae sive Novi Orbis.

The Spanish had silver in abundance, thanks especially to the fabulously rich Cerro Rico ('rich hill') mine in Potosí, Bolivia, high in the wind-swept Andes, and other silver mines in the Americas, such as in Mexico. Quechua Peruvian Native Diego Huallpa chanced upon Cerro Rico in 1545, while working for Spanish overseers at the nearby mine of Porco. Cerro Rico was the biggest silver ore deposit known to humanity at that time. Mined under horrific conditions, mostly by enslaved or conscripted Indian labor, the silver was refined and smelted onsite through a process requiring large quantities of mercury. ${ }^{19}$ The silver was packed overland to ships in ports such as Lima, where it was then transported to other ports; that bound for Asia was taken to Acapulco. The silver from these mines provided Spain with tremendous 
wealth and its principal access to the dizzying diversity of Asian trade goods. The annual galleon returning from Acapulco carried the silver to pay for Chinese goods and to support the Philippine colony's administration. ${ }^{20}$ The Manila trade was crucial to the Philippine colony, as up to half the Spanish government's annual support payments for its maintenance came from taxes on the trade. ${ }^{21}$

\section{THE LONGEST VOYAGE IN THE WORLD}

Although the profits were enormous, the voyage from Manila to Acapulco was a nightmare. The westward journey to Manila was usually fairly smooth sailing for about three months on trans-Pacific currents, but the same could not be said for the eastern voyage to Acapulco. The first, and frequently the most dangerous, part of the voyage involved leaving Manila and reaching the open sea. This required threading a passage through the Straits of San Bernardino (known in Spanish times as the Embocadero), a treacherous maze of shifting tides, heavy currents, invisible shoals, and low-lying islands subject to seething waves, vicious squalls, and thick fogs. It often took the Manila galleons a month or longer just to clear the Embocadero, and many were lost in this region. Galleons were also frequently becalmed for days, and lost further time at ports in the vicinity (such as Jacinto or Ticao) where they put in for fresh water and stores before continuing the voyage. ${ }^{22}$

Once reaching the open sea, the galleons sailed the North Pacific, which is notoriously tempestuous, especially when galleons departed too late in the season, sometimes crossing in the fall and even winter. In the northern seas, galleons were rocked with severe storms, gales, and rain squalls. ${ }^{23}$ The galleons faced additional weather hazards as they approached the northwest coast of America. Prevailing westerlies cause a gentle southward-flowing ocean current along the coast (the California Current) in spring and summer. But the Aleutian low-pressure system moves into the North Pacific each winter, bringing high winds, rainfall and sea swells. Powerful cyclones produce strong south winds, reversing nearshore ocean currents and producing the swift northward-flowing Davidson current. Thus, a galleon approaching North America too close to land and too far into the winter season would find it nearly impossible to sail southward to Acapulco. ${ }^{24}$

In tempestuous weather, masts, sails, and other critical gear could fail, requiring makeshift fixes far out to sea. The journey could, on rare occasion, take as little as four months, but commonly took six to eight months, or even longer. The most infamous Manila galleon voyage was that of the San José of 1657 , which was discovered drifting south of the port of Acapulco, intact, 

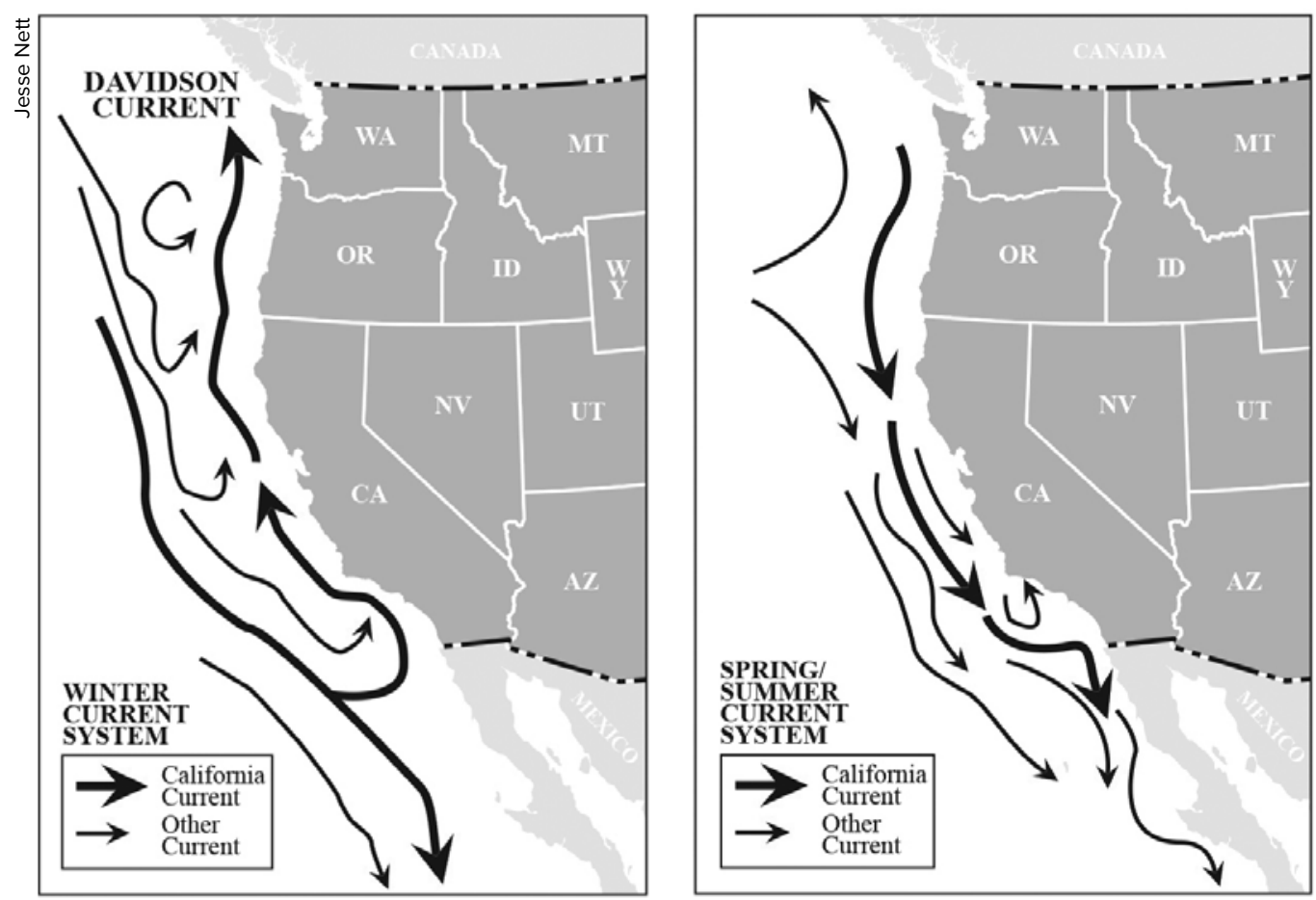

THESE TWO MAPS illustrate the annual cycle of alternating Pacific Ocean currents off the Northwest coast. Ocean currents change seasonally: the strong Davidson current flows northward in the winter cyclone season, but the gentle south-flowing California Current dominates in spring and summer.

with all cargo undisturbed - but the entire crew, down to the last man, dead of starvation or disease. It had been at sea for more than a year. ${ }^{25}$

Careri, aboard the Acapulco-bound galleon San José in 1697, wrote an invaluable description of the voyage and of life aboard a galleon. At the onset of the voyage, the menu included fresh fruits, vegetables, swine, and hens for meat and eggs; at this stage of the trip, he described the galleon as "like a floating garden." ${ }^{26}$ But stores dwindled and the food became scarce and rotten as six months or more dragged by, even if passengers had their own stashes of sweetmeats, beans, olives, and chocolates, as the wealthy often did. ${ }^{27}$

Careri chronicled the deteriorating food in a vivid passage:

Abundance of flies falls into the dishes of broth, in which there also swim worms of several sorts ... I had a good share in these misfortunes; for the boat-swain, with whom I had agreed for my diet ... banished from his table all wine, oyl and 
vinegar; dressing his fish with fair water and salt. Upon flesh days he gave me tassajos fritos, that is, steaks of beef, or buffalo, dry'd in the sun or wind, which are so hard that it is impossible to eat them, without they are first well beaten ... nor is there any digesting them without the help of a purge. At dinner another piece of the same sticky flesh was boil'd without any other sauce but its own hardness, and fair water. At last he deprived me of the satisfaction of gnawing a good bisket, because he would spend no more of his own, but laid the king's allowance on the table; in every mouthful whereof there went down abundance of maggots, and gorgojos chew'd and bruis'd. On fish days the common diet was old rank fish boil'd in fair water and salt; at noon we had mongos, something like kidney beans, in which there were so many maggots, that they swam at the top of the broth, and the quantity was so great, that besides the loathing they caus'd, I doubted whether the dinner was fish or flesh. The bitter fare was sweetened after dinner with a little water and sugar; yet the allowance was but a small coco shell full, which rather increas'd than quench'd drought. ${ }^{28}$

Careri also described the two dread diseases aboard the Manila galleon: scurvy and beriberi. Deaths from both were common on all Manila galleon voyages, as they lasted too long to keep fresh fruits and vegetables. Careri wrote, "There are two dangerous diseases on this voyage, more especially as they draw near the coast of America; one is the aforesaid berben [beriberi], which swells the body, and makes the patient dye talking. The other is called the Dutch disease, which makes all the mouth sore, putrifies the gums, and makes the teeth drop out. The best remedy against it, is going ashore. This is no other but the sea scurvy." 29 It is now known that scurvy is caused by lack of Vitamin $C$ in the diet, and beriberi by lack of Vitamin B, but this was not understood in Manila galleon times.

The finest galleon cabins, which were part of the ship, were reserved for the gal-

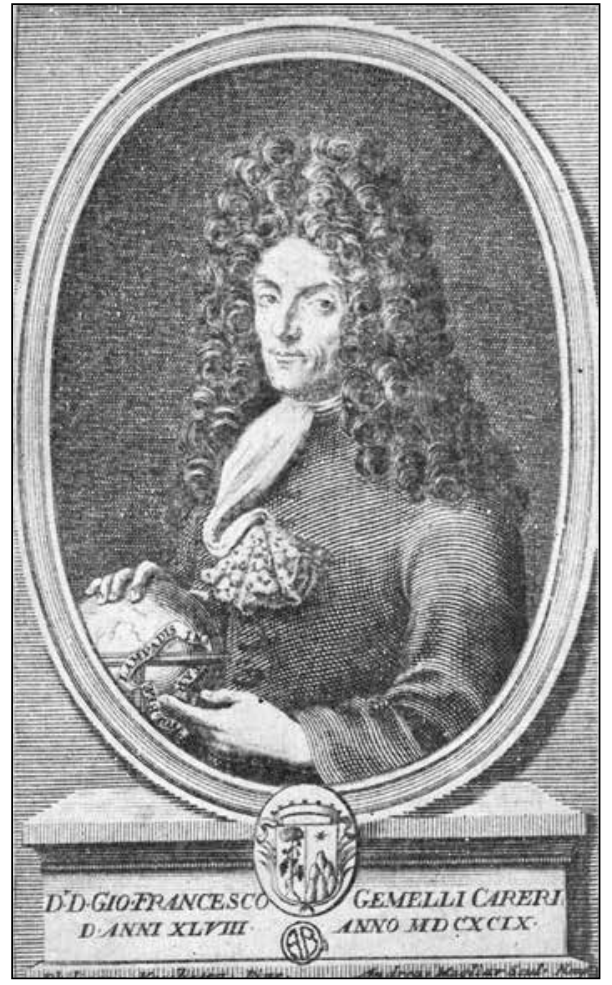

GIOVANNI GEMELLI CARERI was a seventeenth-century Italian adventurer. In 1697, he was a passenger on the Acapulcobound galleon San José and wrote a very important chronicle of his journey. Because he traveled only four years after the loss of the Santo Cristo of 1693, his account is invaluable in describing contemporary conditions on board a Manila galleon. Careri is pictured here in a 1699 illustration published in Giro Del Mondo. 


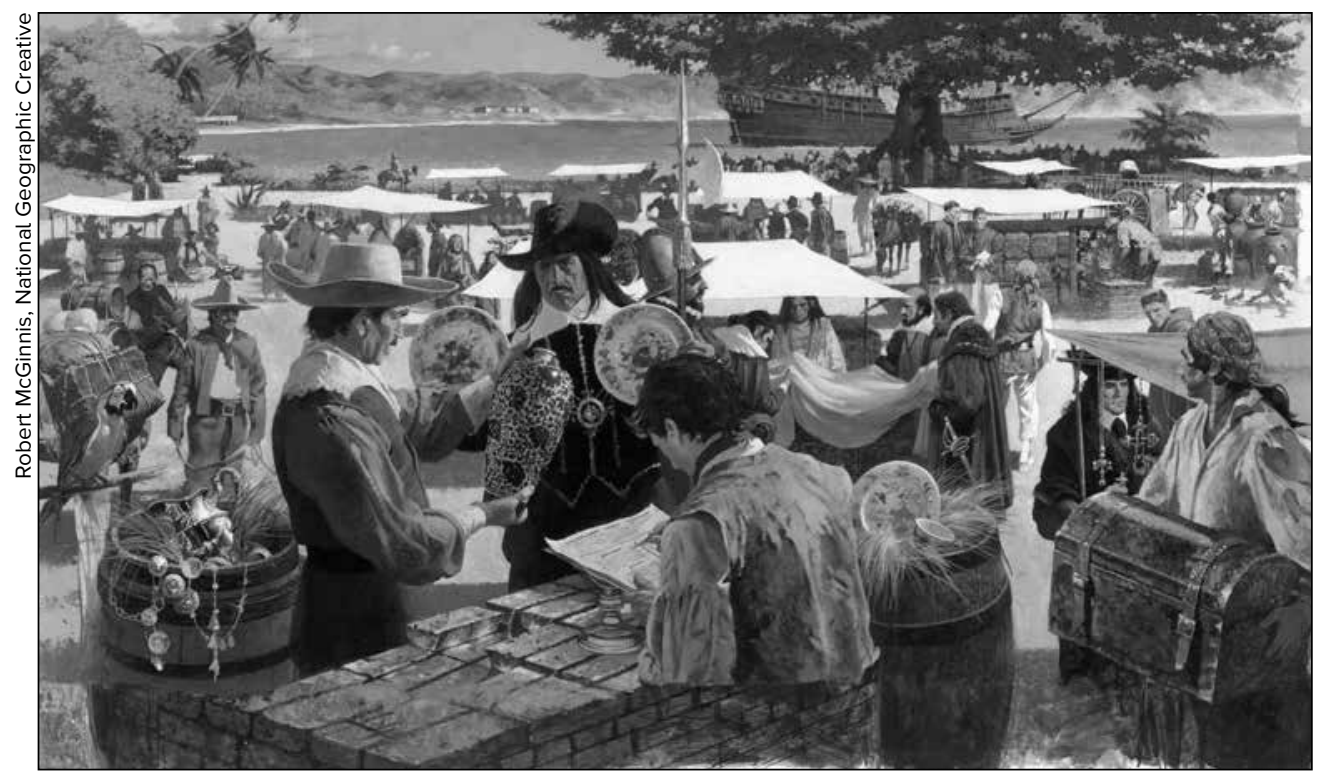

IN ACAPULCO, the Manila galleon's glittering array of Asian goods, ranging from blue-andwhite Chinese porcelain to ivory statuettes, lacquer furniture, silks, and jewelry, were sold at a trade fair attended by merchants from throughout New Spain (Mexico) and Peru. This painting is by artist Robert McGinnis.

leon commander, the chief pilot, and the ship's master. These were high on the sterncastle; the commander's cabin had windows - and, thus, natural light. Lower officers had smaller cabins on the sterncastle, or slept in hammocks at their place of duty. Soldiers, sailors, apprentices, and pages slept on mats or in hammocks, covered with a blanket, usually on one of the decks for the fresh air. Passengers with ability to pay, such as aristocrats or important government officials, purchased the few other available cabins, in the sterncastle or on the upper decks, where they were separated from the stench of the lower decks and the holds. But for most passengers, options were limited: space on a Manila galleon was very dear, since the main purpose of the trip was cargo transport. Passengers with means could pay the ship's carpenter to construct small cubicles for them, preferably on the upper decks. Cabins were tiny on seventeenth-and eighteenth-century galleons, ranging from eight feet wide by ten feet long (in the case of a slightly larger one) to average ones about five feet square. The cabins, especially smaller ones, were usually partitioned from one another by thin wood walls or canvas sheeting. This sometimes led to a crowded warren of tiny chambers that further increased the cramped 
nature of the voyage. Passengers were allowed to bring their food and two trunks of their personal possessions on board. ${ }^{30}$

The original sources all indicate that the Manila galleon crossing featured constant storms, enormous populations of rats, unspeakable food as the voyage ground on, scurvy and beriberi taking their constant toll, no lights allowed after dark for fear of fire, and extremely cramped conditions in a damp wooden ship for months on end. It is no wonder the Manila galleon trade was considered so risky, in spite of its vast rewards. Profits were enormous - if the ship arrived safely.

\section{OF SMUGGLING, CARGO, AND THE SPANISH CROWN}

The economy of the Spanish colony of the Philippines completely depended on the Manila galleon trade. And, importantly, there was usually only one crossing in each direction per year. The written record makes it clear that the loss of a single ship devastated the colony. The Spanish Crown owned all the galleons and frequently issued edicts regulating the Manila trade from Madrid. The monarchy wanted to keep the Manila trade open to all citizens rather than restricted to a few merchants, and this created a detailed bureaucracy charged with oversight of the permiso (permission), which limited the annual value of the Manila trade's cargo to a specified sum. The permiso essentially created an export quota for the colony. Designation of the amount of lading space available on the galleon was only the beginning of the regulatory chain. ${ }^{31}$ Although burdensome during its time, the dense tangle of regulatory controls produced a rich archival record that significantly informs much detail in the articles that follow.

Nearly all levels of society participated in the trade. Galleon officers and common sailors invariably shipped goods. The cargo was of utmost importance to all crew members and to most passengers. Smuggling extra cargo aboard a Manila galleon was commonplace, as the profits were so high - much higher, usually, than what could be fetched for the same goods in Europe or its colonies. Historian William Lytle Schurz described it aptly:

The usual overloading of the galleon and the exceeding of the permiso can only be explained by the habitual laxness or downright corruption of those charged with the surveillance of the work of embarkation... . A law of 1608 required that the cargo should be restricted to the main hold, while the extra sails and tackle, the provisions and the chests containing the seamen's effects were to be stowed between decks. Every cubic inch of space in the hold was crammed with merchandise. ... Not only was this space filled to capacity, but in spite of the law of 1604 [limiting the value of the annual cargo] the ships were habitually overloaded. Bales and chests were piled in the cabins and passage-ways and 
along the decks. They were stowed in the compartments reserved for necessary stores and supplies and in the powder-magazine itself. ${ }^{32}$

The government persistently tried to limit the constant and often large-scale smuggling that took place during the entire history of the trade, but in this, the Crown failed. The profits were too high, and too many Manileño officials and merchants had stakes in the smuggling. In 1635, an incorruptible Royal Commissioner named Pedro de Quiroga y Moya arrived in Acapulco to tighten the trade's notorious laxity. He investigated vigorously, revalued galleon cargos, and imposed steep duties. When word of his severities reached Manila, merchants there refused to freight another galleon to Acapulco for two years, until he was removed. ${ }^{33}$

Careri described smuggling, which took place on his 1697 galleon, in the personal terms of an observer:

The governor being inform'd of it, sent Colonel Thomas de Andaya to lighten the ship. Andaya came on Sunday the 24, and caus'd all the casks of water to be taken out; for the burden of the vessel being 1,500 bales, they had put aboard 2,200, besides provisions and other necessaries. On Monday 25, the colonel caused abundance of bales, and parcels of wax to be unshipp'd, leaving only the 1,500 bales the ship was entred for. ... Tuesday 26. . . This time they had made two cisterns, on the sides of the ship... and these had proved very good; yet they were broken to stow more bales in their place... This was done because the officers put bales of their own in those places, notwithstanding the king's prohibition, they not minding that they sent so many men to perish with thirst, in such a spacious sea. In fine, on Wednesday 27th, 800 barrels of water were cast away, by breaking the cisterns; and the same was done on Thursday following being the 28 , the bales belonging to the colonels friends and acquaintance, being put aboard again. ${ }^{34}$

Careri further noted that seamen, officers, and mates all had packages aboard and expected to make a fine profit on their sale in Acapulco. It was a key incentive for men to undertake so arduous a voyage when the official salary was meager - even for the officers, and much more so for the seamen - and the privations so great. ${ }^{35}$

\section{SHIPWRECKED MEN AND NATIVE AMERICAN ORAL TRADITION}

Castaways are always in an unenviable position: far from home, deposited on unfamiliar and sometimes barren shores or in territories where people have entirely different language, culture, and customs. This latter fate overtook the men of the galleon wrecked on what is now Nehalem Spit in Oregon. What little we know of the circumstances of the wreck and its survivors requires 
a shift in sources from Spanish archival documentation to both archaeology and Native American oral tradition. This oral tradition, transmitted over time to the non-Native community, was instrumental in Oregon's longstanding recollection of, and fascination with, the notion of a vast shipwreck near Nehalem. Ultimately, these stories were also instrumental in fueling wild treasure-seeking speculation, as described in the final article of this issue.

This wreck is the first clearly documented case of European, Asian, and Meso-American contact with Native peoples on today's Oregon coast. Oregon's experience was not entirely unique: first encounters between European peoples and Indigenous peoples were a commonplace, and often accidental, outcome of the galleon trade in many parts of the Pacific.

The wreck of the Manila galleon San Agustín in November 1595 in what is now tamál-húye, the Coast Miwok name for present-day Drakes Bay at Point Reyes National Seashore in California, provides the nearest example of a galleon wreck to the one on Nehalem Spit. It took place a century earlier, however, and the circumstances were quite different: Captain Sebastian Rodriguez Cermeño, returning to Acapulco from Manila with a full cargo of Asian trade goods, anchored in tamál-húye with an eye to coastal exploration. But a storm wrecked the ship, and Cermeño and the surviving crew and passengers had to modify a small ship's launch to sail back to Mexico. They had encounters with the Miwok people for more than a month, according to the sketchy Spanish accounts. Initial interactions were peaceful, but Cermeño ultimately had to abandon the galleon and its cargo, after salvaging necessary materials. The Spanish salvaging caused conflict with the Miwok, who were engaged in the same activity. Cermeño and nearly eighty men made it safely to Mexico, most in the salvaged boat, but some, incredibly, by walking the entire distance. ${ }^{36}$

From the available Native American oral history in Oregon, especially that of the Nehalem-Tillamook and Clatsop peoples, it seems that a fair number of the approximately two-hundred-man crew and sixteen passengers of the galleon wreck (most likely the Santo Cristo de Burgos) survived the disaster and remained on the coast near the broken ship for some weeks or months, living precariously and probably dependent on Native largess, hoping for rescue by Spanish search ships from Mexico. But no one came. ${ }^{37}$ The men had three choices: they could seek to return to Mexico by land or by sea in small, makeshift watercraft, a distance of some 3,000 miles; they could remain on the coast, perhaps integrating with and marrying into the Native community, or at least hope to stay in the good graces of the local people; or they might become victims, being taken as slaves, killed, or otherwise engulfed in inter-ethnic conflict. 


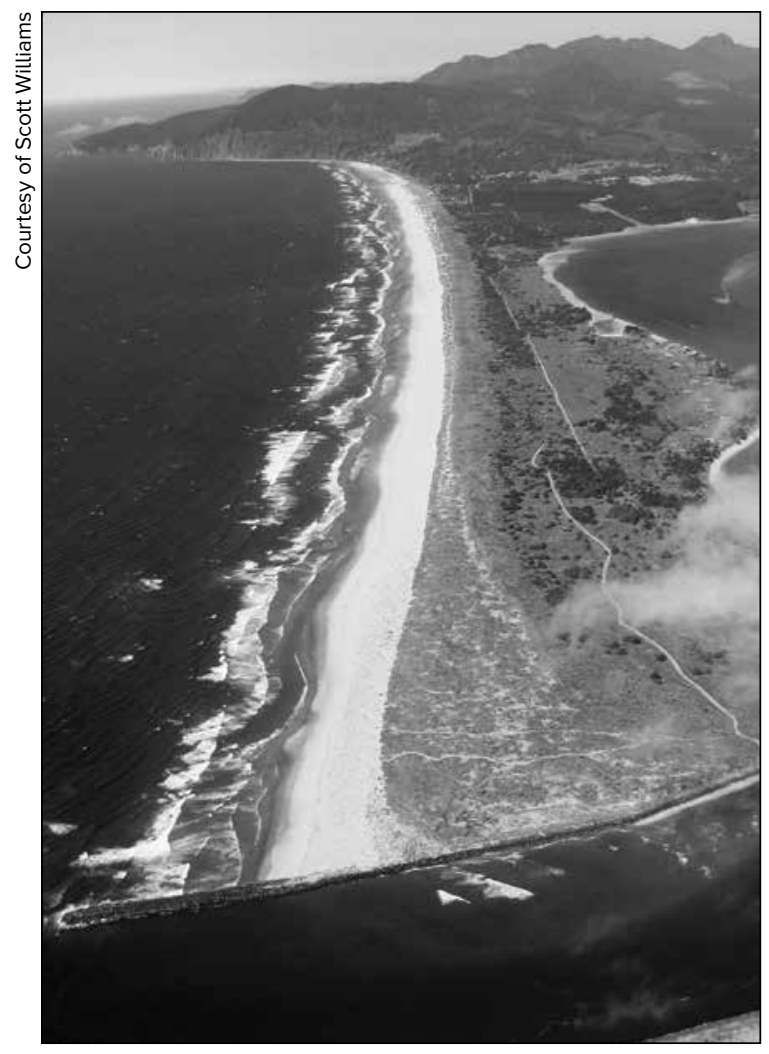

THE NEHALEM SPIT is a long bar of sand that stretches from the base of Neahkahnie Mountain in the north for several miles to the entrance of the Nehalem River. Geological evidence shows that this spit was breached by the tsunami produced by the Cascadia earthquake in January 1700.
Apparent mention of the wreck in the oral tradition of coastal Native peoples was arguably one of its most enduring outcomes. Much has been written about these oral traditions, especially in the popular and early historical literatures of the Pacific Northwest, with accounts varying considerably on the particulars. There is every reason to believe that the original oral tradition regarding this wreck was precise and internally consistent; when studying Nehalem-Tillamook oral tradition, researchers found that - as a matter of cultural conventions and protocols - the same stories were told not only with consistency of content but often with identical phrasings, even by storytellers separated by considerable time and distance. ${ }^{38}$ Nonetheless, the oral traditions come down to us in fragmentary form. This happened for many reasons, including that interethnic communication had many complexities that inhibited full transmission. Language barriers, traditional tribal restrictions on the sharing of certain information, and early tourists' penchant for tales of adventure, conflict, and treasure no doubt skewed some key facts. The tribal community that appears to have housed the shipwreck survivors, moreover, was affected by the subduction zone earthquake and tsunami of January 1700 - a mere six years after the illfated voyage of the Santo Cristo de Burgos. This disaster no doubt affected transmission of oral traditions on many topics, including those related to the wreck. Its effect was soon compounded by a succession of disease epidemics that decreased the Native population of the northern Oregon 
coast to a minute fraction of its original total. These traumas were compounded again by Euro-American settlement, violence, forced relocations, and other shocks, so that the communities had been dramatically reduced, displaced, and dislocated by the time they shared these oral traditions with people who recorded the accounts in written formats. That oral traditions persisted at all, even in fragmentary form, in the wake of these disasters might be seen as remarkable and as testament to the resiliency of Native peoples and oral traditions of the region. ${ }^{39}$

While known Native shipwreck accounts may conflate more than one wreck, certain themes emerge fairly consistently in the Nehalem-Tillamook oral traditions available to date that seem to match what we anticipate for the galleon: survivors wash ashore, apparently while Native eyewitnesses are absent and upriver, possibly suggesting a late winter landfall; survivors are first encountered away from their ship on the protected Nehalem Bay side of Nehalem Spit; and survivors are taken in and establish congenial relationships with the local community, at least initially. Multiple accounts mention that survivors demonstrated skills at metalsmithing - a practice of much interest to the Native community. The survivors express homesickness, and some begin to fraternize with, marry, or make unwanted advances on Nehalem-Tillamook women. Some portion of the men possibly leave by foot, never to be seen again; according to some accounts, the survivors are eventually killed in whole or in part by resident or nearby peoples, due especially to conflicts emerging from their culturally inappropriate treatment of Native women. The closest we might yet come to a likely original Nehalem-Tillamook oral tradition is arguably the version shared in 1931 with linguist May Mandelbaum Edel, then a Columbia University graduate student, who recorded a version of the story in the Nehalem dialect of the Tillamook language during her interviews with tribal elders living near Garibaldi. Translated, it describes the events in these terms:

These Indians lived there at Nehalem. They had gone upriver hunting elk. One old man paddled downriver alone.

At Cronan Point [where the river opens to broad, lower expanse of Nehalem Bay] he saw people, but he didn't know what kind they were.

Their clothes were dark with bright buttons.

Still, the Indians went over to these people. The old man didn't land.

They threw him beads and dentalium shells. These things fell in his canoe.

He paddled back upriver.

He didn't land, for he was afraid. 


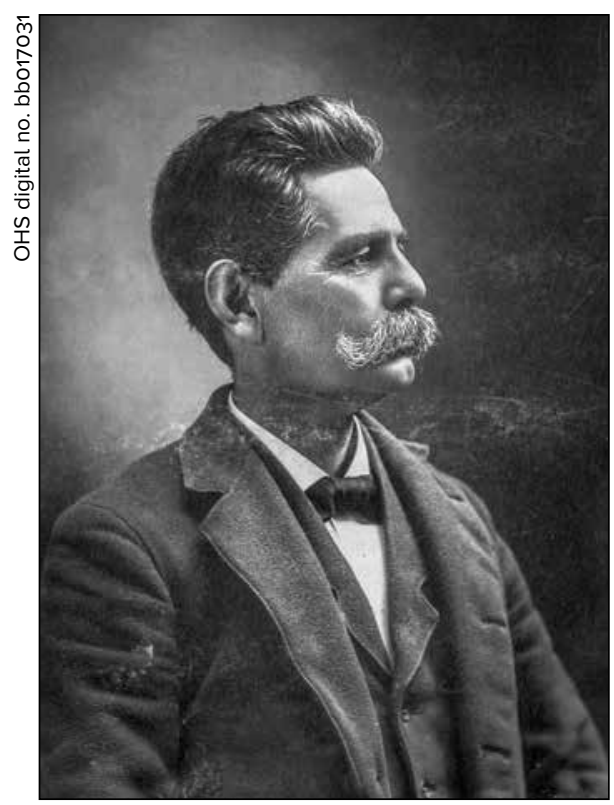

SILAS SMITH, pictured here in an undated photograph, was the son of Celiast, daughter of Clatsop Chief Coboway, who hosted the Lewis and Clark Expedition, and Solomon Smith, one of the earliest Clatsop County pioneers. Smith was instrumental in documenting the Native traditions of the galleon wreck through influential writings first published in the Oregon Historical Society meeting minutes of 1899 .
The old man went back to his people, and told what he had seen.

He showed them the beads. Then, the next day they all went down.

The women, the wives of the Indians, wanted to see the beads.

The women all landed. The white man gave out beads to the women.

These men fed the Indians hardtack and molasses.

Soon the white men wanted women.

They took beeswax ashore.

They kept on taking things ashore, then they packed a large chest with money in it. They buried that chest deep in the ground.

Some of the white people went away then. The rest stayed with the Indians.

The white people who stayed learned to speak Tillamook.

They tried to teach us Indians the white people's language.

The Indians didn't learn much of it, though.

These men cut iron and hammered it cold to make a knife.

One white man took the iron and put it in the fire. He was going to teach them about it.

One Indian grabbed the iron. He said, "He burned the iron!" The white man laughed at him.

Finally the white men got tired of staying here. They wanted to go back home. In the evenings at sunset, these white men cried. They were lonely. And the white men said, "We come from over there, where the sun comes from." Finally they said, "Let's go."

They all went north. They were not seen in Nehalem again. ${ }^{40}$

Again, although an original account, it is possible that even this version conflates multiple wrecks and other shipwreck survivor experiences, with 
its references to molasses, buried chests, and other elements not known to be part of the galleon wreck. Other oral traditions also provide clues as to what transpired after the wreck. Accounts apparently provided by Celiast - daughter of Clatsop Chief Coboway, the principal chiefly host to the Lewis and Clark Expedition during their 1805-1806 stay at Fort Clatsop - describe the survivors as having "tails on their heads," long ponytails that the children pulled playfully. This is consistent with Native Filipino mariners' hairstyles of the late seventeenth century, although admittedly it is consistent with other mariners' hairstyles as well. ${ }^{41}$ Other accounts, probably derived from the same threads of Native American oral tradition, assert that "the [ship's] stores were collected and placed within a rudely constructed house made of driftwood and bark, the beeswax was left to sink into the sands." 42

Oral tradition recorded by Silas Smith - a trained historian and the son of Celiast - corroborates reports of violent clashes resulting from shipwreck survivors' actions toward Native women. Smith reported:

Sometime ago, before the coming of the whites, a vessel was driven ashore in the vicinity of where the beeswax is now found, just north of the Nehalem River. The vessel became a wreck, but all or most of her crew survived. A large part of her cargo was this bees-wax. The crew, unable to get away, remained there with the natives several months, when, by concerted action the Indians masacred [sic] the entire number, on account, as they claimed, that the whites disregarded their - the natives' - marital relations. The Indians also state in connection with the massacre, that the crew fought with slung-shots [sic]. It would appear from this that the [survivors] had lost their arms and ammunition. ${ }^{43}$

Clues to the chronology of events also emerge from these oral traditions. Based on his frequent discussions of the wreck with Tillamook tribal members in the 1850s, for example, early settler Warren Vaughn pinpointed the wreck to the late 1600 s or very early 1700s: "Not an Indian was living who had seen the ship, and all they knew came from their ancestors. The story told by the oldest Indians in about 1860 to 1870 was that a very long time ago, about a hundred and fifty or two hundred years ago, a ship came ashore and wrecked on Nehalem beach." ${ }^{44}$ Consistent with other observers, he reported that beeswax and camphor wood (as he termed it) regularly washed ashore in the Nehalem area from that wreck in the mid to late nineteenth century.

Like many writers of his time, Vaughn noted a separate oral tradition regarding two ships battling and one crew pulling ashore and depositing a large chest in the ground near Neahkahnie Mountain. Also like other early recorders, Vaughn was emphatic that the galleon and this "treasure ship" were two different vessels, separated by perhaps a century, the galleon 
wreck being the first and much more influential event of the two. He based that conclusion on tribal oral tradition, reporting: "Some men argue that the beeswax ship and the treasure ship is one, that the men, after being wrecked, buried their money on the mountain. But witnesses who saw the treasure ship lived here when I came here [ca. 1851] and none claimed to have seen the beeswax ship." 45 Silas Smith reached similar conclusions, based on a separate body of Native oral tradition at his disposal. ${ }^{46}$

Oral traditions also attest that, in addition to stories, the galleon wreck may have left a genetic imprint. Possible descendants appear prominently in the early written historical literatures of Oregon. From the time of Lewis and Clark, explorers' and early fur traders' accounts make frequent mention of "red-headed Indians" on Oregon's north coast. ${ }^{47}$ These men, some of them key Native American figures in the early fur-trade era, are mentioned frequently through the first two decades of the nineteenth century - Ramsay/ Lamazee and unnamed others being so described. On genetic evidence alone, it is nearly certain that such red-haired individuals descended from not one but two parents with European ancestry, dating their family's European roots to arrivals in the generation of their grandparents or before. ${ }^{48}$

In 1811, fur trader Gabriel Franchère encountered a descendant of a Spanish shipwreck survivor while ascending the Columbia River Gorge:

We found here an old blind man, who gave us a cordial reception. Our guide said that he was a white man, and that his name was Soto. We learned from the mouth of the old man himself, that he was the son of a Spaniard who had been wrecked at the mouth of the river; that a part of the crew on this occasion got safe ashore, but were all massacred by the Clatsops, with the exception of four, who were spared and who married native women; that these four Spaniards, of whom his father was one, disgusted with the savage life, attempted to reach a settlement of their own nation toward the south, but had never been heard of since; and that when his father, with his companions, left the country, he himself was yet quite young. ${ }^{49}$

There is no evidence that "Soto" was descended specifically from the Nehalem Spit wreck, but he may have been; the records simply do not allow us to answer this question. This account, however, gives us added confirmation that castaways from European shipwrecks sometimes intermarried with the region's Native residents.

One more individual worthy of mention is Chief Kilchis. He was a formidable leader of the contact period, one of the last two Tillamook chiefs to preside over Tillamook Bay, and often acknowledged as a peacekeeper during the precarious period of Euro-American colonization. He was also widely reported to be strikingly distinct from other tribal members in appearance, reflecting what many assumed to be partial ancestry from sub-Saharan Africa: "a large 
man with African features, his hair was curly ... a flat nose, thick lips and long chin ... an African foot, curly beard." ${ }^{0}$ Settler Warren Vaughn, who knew Kilchis, notes that he asserted ancestry from the galleon wreck's survivors. ${ }^{51}$

Although the precise origins of these various individuals is still debated today, such people - exceptional either in physical attributes or in claimed descent from shipwreck survivors of the period - appear frequently in some of the earliest explorers' accounts of Oregon. Their presence can be reasonably interpreted as evidence of not one or two survivors but several at least, and the linkages between these individuals and Spanish shipwreck survivors is a common and recurring theme. Indeed, the chronology seems a plausible match for a late-seventeenth-century galleon wreck and perhaps other ships washing ashore soon thereafter, such as the so-called Konapee wreck just south of the Columbia River mouth. ${ }^{52}$

\section{ORAL TRADITIONS OF GALLEON WRECKAGE ON LAND AND SEA}

Beeswax and porcelain fragments occasionally appear on the beaches of Nehalem, even in recent times. Their distribution is so scattered, however, that these objects are not an independently reliable clue as to the location of the galleon wreckage. On the matter of wreckage and its location, we must also rely extensively on consistent patterns in local oral traditions. Native traditions as well as the earliest Euro-American accounts indicate that part of the galleon sank offshore - probably the heavier sections with the cargo and weaponry - while a significant portion of the hull, sterncastle, or both remained scattered in one or more locations on Nehalem Spit, buried now under many feet of sand. Local historian Eb Geisecke collected many later oral histories of reported debris sightings from longtime residents of the Nehalem Bay area and pinpointed ten possible locations for wreckage on land. All accounts concurred on one main point: a large amount of the wreckage lies buried on the central to southern portion of Nehalem Spit south of Manzanita, now part of Nehalem Bay State Park. ${ }^{53}$

Oral traditions also consistently relate that the shifting sands in this area have sometimes revealed, and then concealed again, significant ship remains. Some portions of the vessel also appear to be lodged close to the shore but visible only during low tides. Observers have tied the locations as belonging to a single ship since Edward M. Cherry, British vice-Consul in Astoria, noted it in 1929. ${ }^{54}$ A McMinnville news article of September 22, 1899, described one such location based on these local accounts: "The old wreck lies high up on a spit ... in a rather inaccessible portion of the country, with a lake behind it in the winter season and the sea in front." The article described the sands having exposed "the hull of an ancient vessel, whose timbers were of teak." 55 Mrs. Harry Tuttle of Winthrop, Washington, whose father-in-law in 1898 recovered 


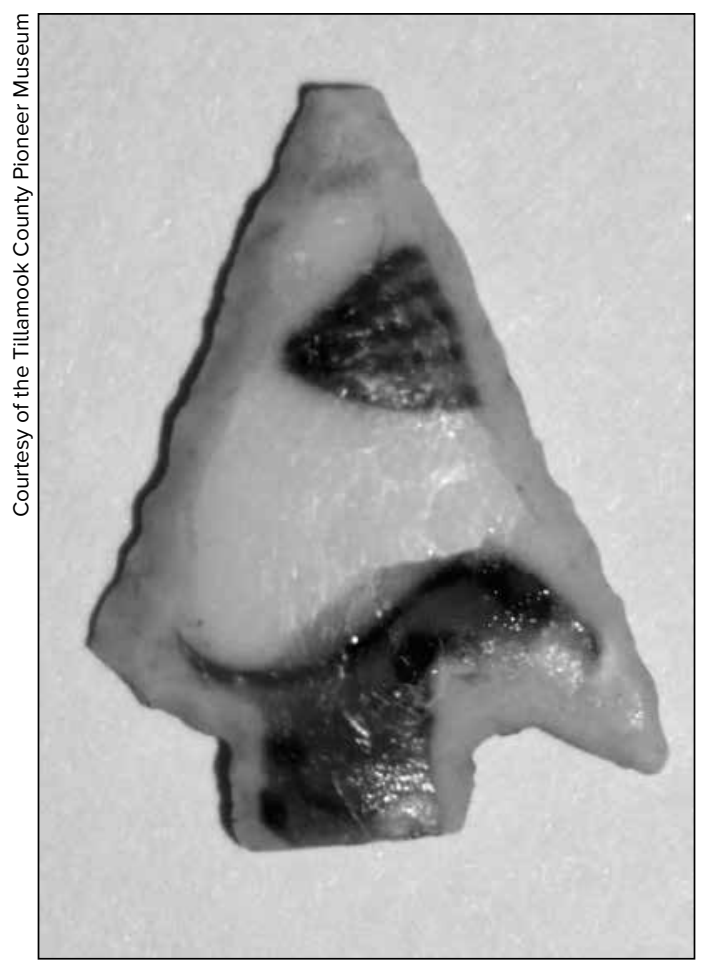

THIS EXQUISITE ARROWHEAD is one of several items made of Chinese porcelain found archaeologically on the northern Oregon and southern Washington coasts. Recovered on the Nehalem Bay sandspit by E.B. Gresham and donated to Tillamook County Pioneer Museum, this arrowhead was likely fashioned by a skilled Nehalem-Tillamook artisan using porcelain from the galleon wreck. a small silver holy oil container near the wreck, reported in 1961 that the wreck, as seen by her husband in his childhood, was on the sandspit between Manzanita and the mouth of Nehalem Bay and that "there were two weather beaten masts sticking up which resembled driftwood." 56 The most recently reported sighting, although not clearly a portion of the Spanish galleon, was described in 1978 by a local resident who saw an old wooden wreck at extreme low tide south of Manzanita. ${ }^{57}$

The principal upland wreck site became both a landmark and an element of longstanding tribal oral tradition. Tribal oral history attests to a Nehalem Spit provenance and to wreckage being alternately exposed and concealed by shifting sands. During his childhood, Harry Scovell - a man of Clatsop and Nehalem ancestry from Nehalem Bay - played on the wreck when it was exposed in the sand and collected beeswax nearby. He noted that part of the keel and ribs could be seen for years after his childhood. His son, Joseph Scovell, longtime Chairman of the Clatsop-Nehalem Confederated

Tribes, claimed to have seen fragments of the wreck in his childhood in the late 1920s, and he continued to visit the site and share knowledge of its location and contents until his death in 2014. Other tribal members have shared elements of the same oral tradition in recent times. ${ }^{58}$

Beyond oral traditions, the wreckage also affected the material culture and trade of Native peoples. Metal and wood salvaged from the wreck were widely reported to be used by Nehalem-Tillamook people, and early metal artifacts in archaeological sites nearby provide possible corroboration of this use. Although likely too fragile for repeated use, arrowheads fashioned from Chinese porcelain have appeared in Nehalem-area archaeological 
sites alongside iron fragments and many porcelain sherds; radiocarbon dates suggest original manufacture of the porcelain occurred between the late sixteenth and early eighteenth centuries. ${ }^{59}$ Tillamook people and their neighbors used the beeswax from this wreck extensively - to waterproof canoes and canvas, as an ingredient in salves for infections, and sometimes as candles. ${ }^{60}$ Various accounts suggest that it became a prized trade good within the region prior to regular European contact. Beeswax has been reported in archaeological sites to the south, in places such as Nestucca, and has continued to erode from archaeological village sites at least as far north as the Quinault Indian Reservation. To this day, certain Quinault tribal members, their ancestors once active traders with the Clatsop, Nehalem, and other tribes of the northern Oregon coast, gather the wax that erodes onto their beaches, using it to waterproof traditional crafts and other items. ${ }^{61}$

Almost immediately, beeswax became a minor article of trade between arriving explorers and fur traders. Members of the Lewis and Clark Expedition made occasional reference to this: "Several of the Clatsop Indians came to the Fort with ... a little bears wax to trade to us." 62 Alexander Henry, an early trader with the Northwest Company, wrote in his 1814 journal: "The old Clatsop chief arrived with some excellent salmon and the meat of a large biche [doe] ... Great quantities of beeswax continue to be dug out of the sand near this spot, and the Indians bring it to trade with us... . They bring us frequently lumps of beeswax, fresh out of the sand, which they collect on the coast to the S., where the Spanish ship was cast away some years ago, and the crew all murdered by the natives." 63

Non-Native trade in beeswax, including settlers' mining of beeswax from recently abandoned villages and burial sites, became a minor cottage industry in the Nehalem region by the mid to late nineteenth century, as well as a source of subdued conflict between settlers and local tribes. ${ }^{64}$ Speculation as to the origins of the beeswax became a popular nineteenth- and early-twentiethcentury pastime for amateur researchers. George Davidson collected samples as part of the 1851 U.S. Coast and Geodetic Survey. ${ }^{65}$ In the early years of the twentieth century, Euro-American settlers and beachcombers excavated great quantities of beeswax from the sands around Nehalem Bay. In about 1906, for example, homesteader E.H. Lane found a single large chunk of the wax weighing over 125 pounds. In 1912, the Hudson family located several hundred pounds of the beeswax. All assumed the wax had come from a wreck, although the ship's identity was unknown; many finders and commentators also noted distinctive markings on the beeswax. ${ }^{66}$

The salvaging of wood provided both clues to the origins of the wreck and source materials for craftspeople into recent times. Patrick Smith, a well-known treasure hunter in Nehalem, found a pulley block from the wreck in 1896 at 
low tide and also retrieved some teak planks. Residents made souvenir canes from salvaged wood, later identified as teak, of the wreck's keel and decks between about 1890 and 1916. Silas Shourds, a Manzanita resident, made a small table from boards of the wreck, and the wood was also tentatively confirmed to be teak from the Philippines or Malaya. ${ }^{67}$ Homesteader E.H. Lane was said to have salvaged some of the teak exposed by shifting sands in the early twentieth century and supplied area residents with the wood for furniture. ${ }^{68}$

\section{THE GALLEON AND THE TRADITION OF TREASURE ON NEAHKAHNIE MOUNTAIN}

Euro-Americans inherited from the Native people of Nehalem Bay not only a tradition of beachcombing galleon flotsam but also the oral traditions that passed through the calamities of the intervening centuries and the difficulties of interethnic transmission, then refracted through their own cultural lens. Much of what is known today about the circumstances of the galleon wreck and its effects on local lives and histories is derived from Native oral tradition codified in fragmentary form by non-Native recorders in non-Native venues and media. ${ }^{69}$ With time and retelling, various wreck stories became conflated and embellished. The stories tended to focus more on wrecks and the possibility of treasure - a foundational element in Neahkahnie Mountain's later preeminence as a regionally infamous treasure-seeking venue.

Accounts of one or more large shipwrecks reached the ears of early explorers and fur traders diffusely and in fragments. By the later nineteenth century, storytellers dramatically and perhaps even intentionally conflated elements from multiple shipwreck episodes. The earliest resort on the north coast, Ben Holladay's Seaside House in modern-day Seaside, Oregon, employed tribal members to tell such stories for the entertainment of guests. Key storytellers included Ed and Nancy Gervais. Nancy (or Nishslush) was a Nehalem-Tillamook woman and daughter of Chief Esahtin (ca. 1804-1884), the last chief to preside over Nehalem Bay before Euro-American. She reported that she "got the story from her father, who heard it from his grandmother, who had learned it from her grandmother."70 Yet, at Seaside House under the management of Holladay — an avid promoter famous for his bravado and boosterism - historical fidelity was not a primary concern. ${ }^{71}$ In this setting, Gervais the storyteller not only was unencumbered by traditional Nehalem-Tillamook prohibitions on embellishment but also had powerful incentives to elaborate. The thin accounts that remain of these tales suggest that she conflated beeswax ships with treasure ships, complete with dramatic battles, murders, pirates, and other elements that do not appear in earlier accounts. In turn, it was on the basis of Gervais's reworking of the 
shipwreck story cycle that Samuel Cotton wrote an influential book of tales, first published in 1915, including Neahkahnie treasure stories. In this version, there had been but one ship, carrying both beeswax and treasure, and from which about thirty sailors survived. According to Cotton:

The Indians living today relate a story, as told to them by their fathers, of the beeswax ship, and add the further fact that a chest or box was taken from the ill-fated vessel and buried on the mountain. Some natives seem to have told the earlier settlers of three ships engaging in battle. It was presumed from this that one of them was a pirate ship and carried the treasure; while the others were merchant ships, one of which carried the beeswax. The story, according to Mrs. Gervais, accounts for only one ship.... Whether it was a pirate vessel or one destined for the Orient, or from the Orient, will always remain a mystery. ... No Indian is supposed to have been sufficiently acquainted with the value of gold or silver to associate the chest or box with wealth.... One of the members of the crew of the treasure ship was a Negro.... Up to this time, neither white man nor Negro had been seen by the natives. According to the Indian story,

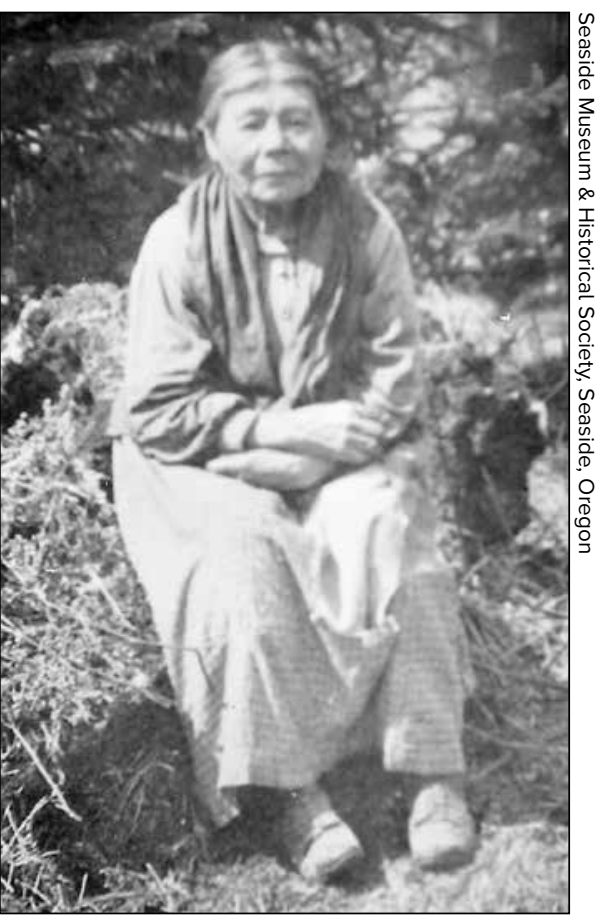

NANCY GERVAIS was the daughter of Chief Esahtin, who presided over the Nehalem Bay area at the time of EuroAmerican settlement. Tribal members widely recognized Gervais as a reliable source of oral traditions regarding shipwrecks and other topics. Early hoteliers, however, encouraged tale-tellers such as Gervais to dazzle their guests with plot devices that did not appear in accounts shared within the tribal community, such as treasure chests, battles, and pirates. the crew dug a deep hole in which the treasure chest or box was lowered. Then they killed the Negro and placed his body upon the chest. .. No people have a more sacred fear of the dead than these natives and, somehow or other, the white visitors discovered this fact. The chest and body of the Negro were then covered with earth and the crew separated, four going north and the remainder building cabins. From this point in the story, the narrative of the Indian is silent. . . Whether the natives ever told the subsequent white men coming here, causing them to search for the gold, is not known, but the new comers, during the past century, have been given all the information possessed by them, but it is so meager that nothing can be gained. ${ }^{72}$ 


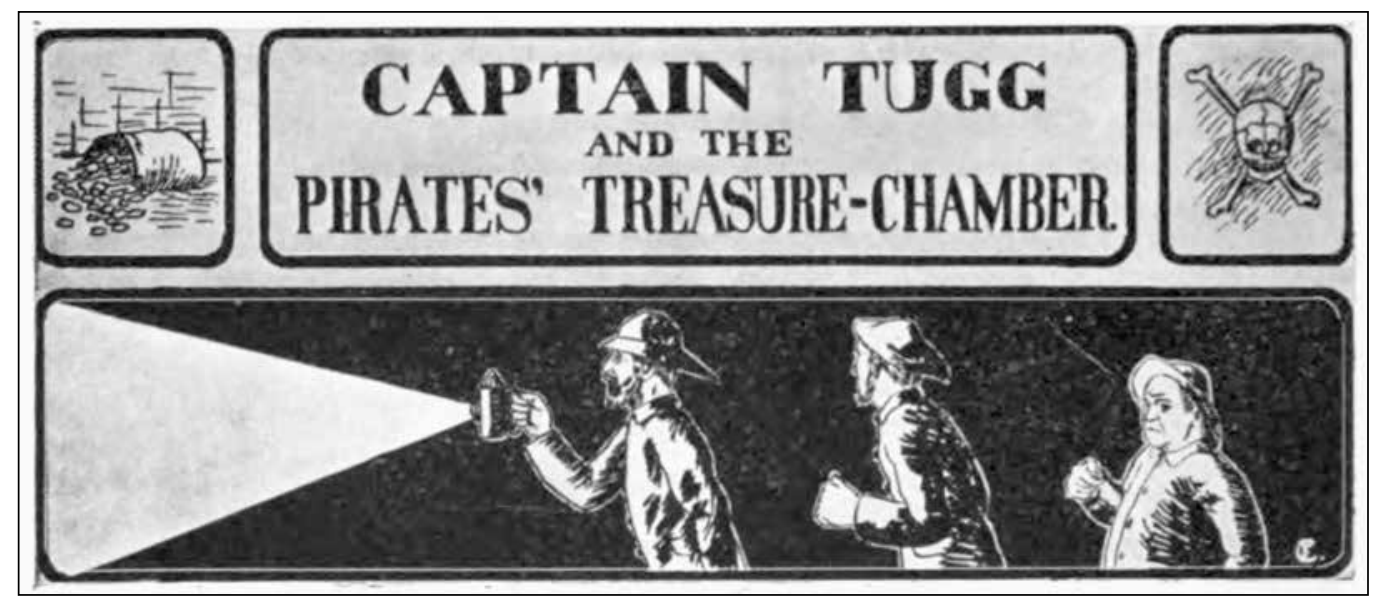

EARLY TWENTIETH CENTURY McMinnville writer Thomas Rogers was an enthusiastic storyteller of Neahkahnie Mountain-area lore of shipwrecks, pirate treasure, smuggling, nefarious deeds, and romance. Rogers was highly influential in both creating and spreading fictional, treasure-oriented tales in Euro-American folklore of Neahkahnie Mountain. This illustration was published in Rogers's article "Captain Tugg and the Pirates' Treasure-Chamber," in the January 1915 Oregon Native Son.

Following these leads, late-nineteenth- and early-twentieth-century writings consistently mixed information about the galleon wreck with speculative tales of treasure and, often, romance. Such fanciful reorganizations of early European shipwreck narratives were significantly encouraged by some of the earliest, heavily fictionalized, popular accounts in sources such as Oregon Native Son. That journal published several romances and treasure tales at the beginning of the twentieth century, none of them clear about which of several possible shipwrecks were their focus. One depicted romance between a Spanish maiden and a Tillamook chief; another, setting the tale in the eighteenth century, between a Tillamook maiden and a European (purportedly Scottish) castaway. ${ }^{73}$

Prolific McMinnville writer Thomas $\mathrm{H}$. Rogers wrote largely fictional accounts about the Spanish ship, treasure-hunting, and pirate lore; his writings and associated self-promotion describe the ship in near-mythic terms. An 1899 article described Rogers's trip to the coast and his meeting with legendary treasure-hunter Pat Smith and also mentioned Native American accounts of two monster canoes fighting one another, with one beaching on Nehalem Spit. ${ }^{74}$ A 1929 article, echoing earlier accounts, described Rogers's talking to Nehalem-area old-timers and hearing tales of: "strange dark men, long before the white man came... [who] unloaded a strong box upon the 
beach somewhere, and that the beeswax ship is filled with gold and jewels - a pirate's ship." Or maybe, the article continues, it was a merchant ship chased by pirates and contained in its hold "jewels and relics of priceless value."75

Like those of other writers, Rogers's multiple versions were not mutually exclusive, and all contained a similar mysterious event or two, linked in most cases to the robust Native American oral history relating to a Spanish wreck. In a story about the treasure of Neahkahnie, Rogers wrote: "The legend of them pirates hidin' a lot of gold in a cave in Necarney Mountain comes mighty near being true,' said Captain Tugg, one evening as he sauntered up to the hotel and seated himself on the veranda, to the gratification of the summer boarders. ... 'Yes,' he continued, 'l've heard a good many stories about the pirates hidin' a box of gold and treasure in a cave in the big mountain'." Rogers then devoted pages to the captain's telling of his story, as he describes what he found that convinced him the yarn of Necarney's hidden treasure was true. ${ }^{76}$ Such stories, widespread not only in fictional accounts but also in local oral and written histories, contributed to a mania of treasure seeking for more than 150 years following Euro-Americans' settling in the region of the old Spanish shipwreck.

Such tales were repeated, often without clarification as to their semifictional basis, in several local newspapers and popular writings. A story in the Wheeler paper, for example, quoted "an old Indian woman" who said the big ship wrecked on Nehalem Spit and the crew tried to repair it. They lowered a heavy box into a hole dug right on the beach and covered it with rocks. Then the paper quoted a partially conflicting account, also said to be of Native origin, in which cargo was strewn all over the beach. Both accounts mentioned the staggering amounts of beeswax left by the wreck. ${ }^{77}$

Beginning in the nineteenth century and escalating in the mid twentieth century, the memories of the Spanish wreck ignited a frenzy of treasurehunting and later created a focus of archaeological examination. Treasure seekers inundated the Neahkahnie area, searching for the elusive bounty these vague and overlapping traditions indicated was buried there. Their efforts led to significant changes in Oregon state laws, including passage and then repeal of acts regulating treasure hunting on state lands and enactment of statutes advancing protection of archaeological sites and artifacts. ${ }^{78}$

It is now clear, from the combination of oral history, archival research, and archaeological investigation, that the galleon's ill-fated voyage from Manila - most likely the Santo Cristo de Burgos in 1693 - ended with all the survivors lost, the rich cargo sunk, dispersed, traded, or buried, and the tale of the wreck obscured but not forgotten. In the subsequent articles, we bring forward the research and archival documentation of Oregon's greatest shipwreck mystery. 
The research in this article was only possible with generous help from the staffs of the Archives of the Indies (Archivo General de Indias) in Seville, Spain; the National Archives of the Philippines (Pambansang Sinupan ng Pilipinas) in Manila; the Archivo General de la Nación of Mexico in Mexico City; and the Archivo General del Estado de San Luis Potosí. We also gratefully acknowledge the help of the Oregon Historical Society's Davies Family Research Library for providing invaluable historical photographs. For information and perspectives on oral traditions associated with shipwrecks and other early encounters, the authors gratefully acknowledge the assistance of the cultural staffs and knowledgeholders of the Quinault Indian Nation, ClatsopNehalem Confederated Tribes, Chinook Indian Nation, Confederated Tribes of Siletz, and Confederated Tribes of Grand Ronde. We also acknowledge the important contributions of the Melville Jacobs Collection in the University of Washington (UW) Special Collections, the Oregon Heritage Commission, the Seaside Museum and Historical Society, the Tillamook County Pioneer Museum, and Laurence and M. Terry Thompson.

1. Silas Smith, "Tales of Early Wrecks on the Oregon Coast, and How the Beeswax Got There," Oregon Native Son, vol. 1 (January 1900): 443.

2. For general overviews of Spanish colonial expansion into South and Central America and its effects, see Henry Kamen, Empire: How Spain Became a World Power, 1492-1763 (New York: Harper Collins, 2003); Hugh Thomas, Rivers of Gold: The Rise of the Spanish Empire 1490-1522 (London: Weidenfeld \& Nicolson, 2004); J.H. Elliott, Empires of the Atlantic World: Britain and Spain in America 1492-1830 (New Haven, Conn.: Yale University Press, 2006); and Alfred W. Crosby, The Columbian Exchange: Biological and Cultural Consequences of 1492 (Westport, Conn.: Greenwood Publishing Co, 1972).
3. Arturo Giraldez, The Age of Trade: The Manila Galleons and the Dawn of the Global Economy (Lanham, Md.: Rowman \& Littlefield, 2015).

4. For general overviews of Spanish expansion in the Pacific, see Henry R. Wagner, Spanish Voyages to the Northwest Coast of America in the Sixteenth Century (San Francisco: California State Historical Society, 1929; Reprint Martino Pub, 2008); and Warren L. Cook, Flood Tide of Empire: Spain and the Pacific Northwest, 1543-1819 (New Haven, Conn.: Yale University Press, 1973).

5. William Lytle Schurz, The Manila Galleon (New York.: E.P. Dutton \& Co., 1939, 1959), 63-70; Giraldez, The Age of Trade, 62-68.

6. Schurz, The Manila Galleon, 17-24.

7. Ibid., 16-25.

8. Ibid., 24-25.

9. Giraldez, The Age of Trade, 126-27. For a recent article arguing that Urdaneta played a subsidiary role in discovery of the galleon return route to Acapulco, see Juan Gil, "El Primer Tornaviaje," in La Nao de China, 1565-1815: navegación, comercio e intercambios culturales, ed. Salvador Bernabéu Albert (Sevilla: Universidad de Sevilla, 2013).

10. Schurz, The Manila Galleon, 69.

11. Ibid.; William M. Mathers and Nancy Shaw, Treasure of the Concepción (APA Publications (HK) Ltd., 1993), 6, 15-20; Shirley Fish, The Manila-Acapulco Galleons: The Treasure Ships of the Pacific (Central Milton Keynes, UK: AuthorHouseUK, 2011), 65, 93-96.

12. Giraldez, The Age of Trade, 30-33.

13. Schurz, The Manila Galleon, 194-98.

14. Giovanni Francesco Gemelli Careri, $A$ Voyage to the Philippines (Manila: Filipiniana Book Guild, 1963), 125.

15. Ibid., 162-63; Fish, The Manila-Acapulco Galleons, 162-63; Schurz, The Manila Galleon, 196.

16. Giraldez, The Age of Trade, 146-48, quoting Schurz, The Manila Galleon, 32. 
17. A.J. Schulte, "Altar Candles," The Catholic Encyclopedia, vol. 1 (New York: Robert Appleton Company, 1907), http://www. newadvent.org/cathen/01347a.htm (accessed March 1, 2018); John Bolen, "The Wax Candle in the Liturgy," The Ecclesiastical Review (Washington, D.C.: American Ecclesiastical Review for Catholic University of America, May 1942) 376-83, https://www.catholicculture. org/culture/library/view.cfm?recnum $=6206$ (accessed March 1, 2018).

18. The Chinese also imported substantial quantities of silver from Japan. See Dennis O. Flynn and Arturo Giraldez, "Arbitrage, China, and World Trade in the Early Modern Period," in European Entry into the Pacific: Spain and the Acapulco-Manila Galleons, eds. Dennis O. Flynn, Arturo Giraldez, and James Sobredo (Hampshire, Great Britain: Ashgate Publishing Limited, 2001), 265-70; and Dennis O. Flynn and Arturo Giraldez, "Born with a 'Silver Spoon': The Origin of World Trade in 1571," Journal of World History 6:2 (1995): 201-205, 208-12.

19. Kris Lane, "Potosí Mines," Latin American History, Oxford Research Encyclopedias (May 2015), http://latinamericanhistory.oxfordre.com/view/10.1093/acrefore/9780199366439.001.0001/acrefore9780199366439-e-2 (accessed March 6, 2018).

20. Giraldez, The Age of Trade, 30-34.

21. Dennis O. Flynn, Arturo Giraldez, and James Sobredo, eds., European Entry into the Pacific, xxxii.

22. Schurz, The Manila Galleon, 221-22.

23. For an invaluable contemporary account of the incessant storms and gales on the Manila galleon crossing, see Careri, $A$ Voyage to the Philippines, 147-71.

24. Stewart T. Schultz, The Northwest Coast: A Natural History (Portland, Ore: Timber Press, 1990), 17-30.

25. Schurz, The Manila Galleon, 265-66. 26. Careri, A Voyage to the Philippines, 135.

27. Ibid., 156.

28. Ibid., 155.

29. Ibid., 163.
30. Fish, The Manila-Acapulco Galleons, 387-94; Giraldez, The Age of Trade, 133-34.

31. Schurz, The Manila Galleon, 154-55.

32. Ibid., 184.

33. Ibid., 186-88.

34. Careri, A Voyage to the Philippines, 126-27.

35. Ibid., 156.

36. Henry R. Wagner, "The Voyage to California of Sebastian Rodriguez Cermeño in 1595," California Historical Quarterly 3:1 (April 1924): 3-24; Matthew A. Russell, "The Archaeology of Sixteenth-Century Cross-Cultural Encounters in Point Reyes National Seashore," National Park Service, n.d., https://www.nps. gov/archeology/sites/npsites/pointReyes.htm (accessed December 18, 2017).

37. For an overview of early Euro-American explorer, fur trader, and settler references to the wreck in Clatsop and NehalemTillamook oral tradition, see Yvonne Hajda "Ethnohistory of the Nehalem Shipwreck" Summary Report on the 1989 Excavations at the Cronin Point Site [35-TI-4B] Nehalem State Park, Oregon (Portland, Ore.: Institute for Archaeological Studies, 1990); and Jon Erlandson, Robert Losey, and Neil Peterson "Early Maritime Contact on the Northern Oregon Coast: Some Notes on the 17th Century Nehalem Beeswax Ship," in Jason Younker, Mark. A. Tveskov, and David G. Lewis, eds. Changing Landscapes: "Telling Our Stories" - Proceedings of the Fourth Annual Coquille Cultural Preservation Conference (North Bend, Ore.: Coquille Indian Tribe, 2001), 45-53

38. See May Mandelbaum Edel, "Stability in Tillamook Folklore," Journal of American Folklore 57:224 (April-June 1944): 116-27.

39. See Robert T. Boyd, The Coming of the Spirit of Pestilence: Introduced Infectious Diseases and Population Declines Among Northwest Coast Indians 1774-1874 (Seattle: University of Washington Press, 1999); and Douglas Deur, “The Making of Seaside's Indian Place: Contested and Enduring Native Spaces on the Nineteenth Century Oregon Coast" Oregon Historical Quarterly 117:4 (Winter 2016): 536-73. 
40. This account has been edited and translated in Douglas Deur and M. Terry Thompson, South Wind Traveled in Winter: A Collection of Nehalem-Tillamook Stories, unpublished manuscript in author's possession.

41. E.W. Geisecke, Beeswax, Teak and Castaways: Searching for Oregon's Lost Protohistoric Asian Ship (Nehalem, Ore.: Nehalem Valley Historical Society, 2007), 55-56.

42. Ibid., 55; T.A. Wood, "Beauty, Beeswax and Rum: The First Landed on the North Pacific Coast. An Indian Tradition," Oregon Native Son, vol. 1 (October 1899): 299.

43. Smith, "Tales of Early Wrecks on the Oregon Coast," 443.

44. Warren N. Vaughn, Till Broad Daylight: A History of Early Settlement in Oregon's Tillamook Country (Wallowa, Ore.: Bear Creek Press, 2004), 81.

45. Ibid., 83.

46. Smith, "Tales of Early Wrecks on the Oregon Coast," 443-46.

47. Gary Moulton, ed., The Journals of the Lewis \& Clark Expedition, Volume 6: November 2, 1805-March 22, 1806 (Lincoln: University of Nebraska Press, 1990), 147; Ross Cox, Adventures on the Columbia River, vol. 1 (London: Colburn and Bentley, 1832), 287; Elliott Coues, ed., The Manuscript Journals of Alexander Henry and of David Thompson, 1799-1814, vol. 2 (New York: Francis P. Harper, 1897), 151-52, 768.

48. Cook, Flood Tide of Empire, 31-33. Cook notes that since dark hair is a dominant gene, a person with red hair must have inherited the genes for it from both parents. This could be the case if one parent descended from the Nehalem wreck and the other from a European deserter or castaway of a later wreck.

49. Gabriel Franchère, Narrative of a Voyage to the Northwest Coast of America in the Years 1811, 1812, 1813, and 1814, J.V. Huntington, trans. and ed. (New York: Redfield, 1854), 112-13.

50. Warren Vaughn, Warren Vaughn's Diary (n.d.), unpublished manuscript, collections of Tillamook Pioneer Museum, Tilla- mook, Oregon [hereafter Tillamook Pioneer Museum].

51. Vaughn, Till Broad Daylight. Much has been written about Chief Kilchis in popular historical literatures, while significant archival material on this remarkable leader remains mostly untapped. Compare J. Sauter and B. Johnston, Tillamook Indians of the Oregon Coast (Portland, Ore.: Binfords and Mort, 1974); and E. Center "Tillamook Indians 1930-1935," unpublished correspondence, J. Neilson Berry papers, Washington State University, Pullman, Washington. See Darrell Millner, "The Death of Markus Lopius: Fact or Fantasy? First Documented Presence of a Black Man in Oregon, August 16, 1788," Trotter Institute Review 5:2 (1991): 19-22.

52. Smith, "Tales of Early Wrecks on the Oregon Coast," 444; Charles Cultee and Franz Boas, Chinook Texts, U.S. Bureau of American Ethnology Bulletin no. 20 (Washington, D.C.: U.S. Government Printing Office, 1894), 277-78.

53. Geisecke, Beeswax, Teak and Castaways, 30-42.

54. Ibid., 47.

55. "An Important Discovery," Yamhill County Reporter (McMinnville), September 22, 1899, in Geisecke, Beeswax, Teak and Castaways, 44.

56. Geisecke, Beeswax, Teak and Castaways, 76. Tuttle's full name is not given in the article.

57. Ibid., 47.

58. Ibid., 35-36, 38; Joseph Scovell, personal communication with Douglas Deur, 2010-2014.

59. Herbert Kyle Beals and Harvey Steele Chinese Porcelains from Site 35-TI-1, Netarts Sand Spit, Tillamook County, Oregon (Eugene: University of Oregon Anthropological Papers, 1981).

6o. Clara Pearson, in Elizabeth Derr Jacobs, "Ethnographic Notes Based on Three Months Fieldwork among the Tillamook Salish, Garibaldi, Oregon," unpublished notes in Melville Jacobs Collection, University of Washington Special collections, Seattle: Erlandson, Losey, and Peterson, "Early Maritime Contact 
on the Northern Oregon Coast: Some Notes on the 17th Century Nehalem Beeswax Ship," 50.

61. Warren T. Vaughn, "An Early History of Tillamook, 1851-52," 134, unpublished manuscript (n.d.), Tillamook Pioneer Museum; Justine James, Jr., Quinault Indian Nation, personal communication with Douglas Deur 2014-2017. There are many Clatsop descendants on today's Quinault Indian Nation rolls, too, reflecting northward migration of displaced Clatsops to Quinault, especially through Chinook family ties during the late nineteenth and early twentieth centuries. See Deur, "The Making of Seaside's Indian Place."

62. John Ordway, March 9, 1811, entry in Moulton, ed., The Journals of the Lewis \& Clark Expedition (Lincoln: University of $\mathrm{Ne}$ braska Press), https://lewisandclarkjournals. unl.edu/item/lc.jrn.1806-03-09\#lc.jrn.1806-0309.03 (accessed May 7, 2018).

63. Elliott Coues, ed., The Manuscript Journals of Alexander Henry and of David Thompson, 1799-1814, 767-68, 841.

64. Vaughn, "An Early History of Tillamook, 1851-52," 134; Scovell to Deur, personal communication, 2010-2014.

65. Orin Stafford, "Wax of Nehalem Beach," Oregon Historical Quarterly 9:1 (Spring 1908): 26.

66. Jane Comerford, At the Foot of the Mountain: An Early History (Portland, Ore.: Dragonfly Press, 2004, 2010), 110-13. In the 1890s, a controversy erupted as to whether the wax might be ozokerite, a mineral wax of economic value. Tests of the wax in the 1890 s and in 1903 conclusively settled it was Asian beeswax. Many chunks of the wax were imprinted with shippers' marks, or trading marks, which would clearly not be the case were the wax a naturally occurring mineral. Orin Stafford reproduced drawings of a dozen of the marks. See Stafford, "Wax of Nehalem Beach," 26-38, 40.

67. Geisecke, Beeswax, Teak and Castaways, 23; John Woodward, "Paleoseismicity and the Archaeological Record: Areas of investigation on the northern Oregon coast," Oregon Geology 52:3 (May 1990): 63.
68. Comerford, At the Foot of the Mountain, 110-11.

69. Consider the accounts of Vaughn, Lyman, Stafford, Wood, and Clark. Silas Smith is an outlier, being both Native, fluent in the language, and still part of Clatsop kinship networks, while also being trained as a writer, lawyer, and historian - a rare combination for his time within Oregon. See also Hajda, "Ethnohistory of the Nehalem Shipwreck"; and Erlandson et al., "Early Maritime Contact on the Northern Oregon Coast."

70. Mrs. John [Mary] Gerritse "Gerritse family," unpublished interview transcription (n.d.), Seaside History Museum collections, Seaside, Oregon [hereafter Seaside History Museum]; Deur, "The Making of Seaside's Indian Place," $561 .$.

71. Seaside History Museum "Seaside House," unpublished manuscript (n.d.).

72. Samuel J. Cotton, Stories of Nehalem, (Chicago: M.A. Donahue \& Company, 1915), 56-58.

73. T.A. Wood, "Beauty, Beeswax and Rum," 299-301; and Samuel A. Clark, "Legend of Nehalem," in Oregon Native Son, vol. 2 (May 1900): 36-40.

74. "An Important Discovery," Yamhill County Reporter, September 22, 1899, quoted in Geisecke, Beeswax, Teak and Castaways, 44.

75. "Low Tide Exposes Hulk of Ship Described in Book Written by Resident Here," Telephone-Register (McMinnville, Oregon), August 22, 1929, quoted in Geisecke, Beeswax, Teak and Castaways, 15.

76. Thomas H. Rogers, "Captain Tugg and the Pirates' Treasure-Chamber," Oregon Native Son, vol. 1 (January 1900), 424-32.

77. "Pirate or Merchantman?" Wheeler Reporter(Wheeler, Oregon), August 15, 1930, in Geisecke, Beeswax, Teak and Castaways, 26.

78. See Cameron La Follette and Douglas Deur, "The Mountain of a Thousand Holes: Shipwreck Traditions and Treasure Hunting on Oregon's North Coast," in this issue of Oregon Historical Quarterly 119:2 (Summer 2018): 192-209. 